\title{
Antonio López-Peláez, Nada puede el sol, Barcelona, Mondadori, 2008, 144 pp.
}

No resulta habitual encontrar una primera novela que sepa conjugar al mismo tiempo una alta exigencia estética con una acertada elección temática. Por eso, en el caso de esta obra de Antonio López-Peláez Manoja (León, 1967) quizás nos encontremos ante una de esas raras excepciones que, significativamente, vienen a dotar de sentido a la norma. Aunque es preciso aclarar que LópezPeláez no es exactamente lo que podríamos denominar un autor novel. En su haber se encuentra ya un libro de relatos (No te duermas, mi amor, mira la calle, 2003) que, pese a haber alcanzado en su día escasa repercusión, trasluce, más allá de los tópicos esperables, la acusada personalidad de un autor con clara conciencia de su labor creadora, que sabe sin duda hacia dónde desea que se encaminen sus ficciones.

La anécdota de la que parte esta obra se basa en un suceso tristemente verídico. En el año 1990, en pleno conflicto bélico, fue dado por desaparecido en la embajada española en Monrovia (Liberia) un diplomático que se negó a ser evacuado del edificio con los otros funcionarios blancos. Su única y fatal condición para hacerlo consistió en pedir que dejasen salir libres con él a los liberianos retenidos en el interior de la embajada por los esbirros del sátrapa y criminal de guerra Charles Taylor. A partir de esa anécdota, de ese desgraciado -y sin duda heroico- suceso y, sobre todo, a partir de sus consecuencias se teje esta obra.

El centro de la novela, la búsqueda del desaparecido, encargada por el gobierno español al protagonista -un funcionario innominado-, se convierte en el centro de la acción que, en una postergación sempiterna de su desenlace, pretende adentrarnos sin miramientos en el vesánico infierno de una Liberia en permanente conflicto. Un conflicto que, como suele suceder, está sustentado en una irracionalidad de naturaleza destructiva, una realidad ensangrentada que podría verse -puestos a buscar una lectura alegórica- como reveladora de la propensión al hundimiento moral del hombre. Interpretar la acción del diplomático desaparecido, ese singular heroísmo que podría ser esperable e inherente a la condición humana, se convierte para el funcionario que sigue sus pasos a través del país en un misterio incomprensible y difícilmente asimilable para su viciada escala de valores. No hay, sin embargo, en la novela una pretensión explícita de interpretar los hechos narrados o explicarlos al lector, tampoco incómodas e innecesarias injerencias manipuladoras por parte del narrador. Los acontecimientos se imponen solos, con gradual y abundante precisión, a la imaginación del lector, optando por una sobriedad formal que busca mostrar en toda su crudeza descarnada esa atmósfera de pesadilla y confusión que supone la búsqueda como motor del relato. 
Como en El corazón de las tinieblas, de Conrad -la comparación parece inevitable-, en la obra de López-Peláez esa búsqueda produce un incómodo y similar asombro, pues revela el inquietante conocimiento del horror como parte de la cotidianidad de un continente como el africano abandonado en manos de su propia crueldad. Sin embargo, no se enjuician los hechos desde el fácil, por vacuo, contraste entre, por un lado, el europeo civilizado y, por otro, esa brutalidad sustentada en los ritos ancestrales de una cultura tribal, sino que la única pretensión aparente del autor se reduce, y no es poco, a mostrar la acción con la mayor asepsia posible, con una sobriedad y pulcritud ejemplares y, al mismo tiempo, con un difícil distanciamiento. Difícil porque el innominado y descreído protagonista es, al mismo tiempo, el narrador. Justifica el artificio de la distancia el hecho de que este personaje procede del universo deliberadamente gris y tedioso de la burocracia. Por ello su única ambición, lo único que parece moverlo a la acción, al menos en apariencia, es realizar el trabajo encomendado, ya sea investigar las posibles irregularidades de una contabilidad o encontrar a un compatriota desaparecido. Como si no hubiese distinción entre tareas tan lejanas. La asepsia se traslada también a la información que se nos da de él, pues esos serán apenas los únicos datos de su biografía que se revelen al lector bosquejados de forma sumamente escueta.

Sin embargo, no es difícil intuir cómo, poco a poco, esa distancia inicial del protagonista ante la realidad podría irse ablandando en su interior, bajo la aparente capa de frialdad, aunque la narración, en su pulcritud y falta de sentimentalismo, apenas lo revele. La frialdad y el distanciamiento iniciales podrían tornarse así en una humanización que afluye en una visión, tal vez menos cínica, pero igualmente dura, cargada de desconfianza hacia los otros, hacia el mundo, como nos revelan las escenas finales. Quizás por ello ese final se muestra carente de toda épica y no eclipsa ni ensombrece la imagen del diplomático desaparecido -constantemente presente in absentia- que se ha ido forjando en la imaginación del lector. Tampoco su condición de enigma para el narrador.

Los otros personajes, tal vez como consecuencia del conflicto bélico en que se hallan inmersos, por esa realidad deshumanizada y desbordante, por ese ambiente de desasosiego y claustrofobia, se muestran a menudo como seres alterados, desequilibrados en contraste con la figura del narrador, movidos por conductas aparentemente irracionales o desesperadas, bordeando peligrosamente los límites de una insondable y amenazadora demencia. Sin embargo, muchos pueden provocar una cierta ternura en el lector, tal es el caso del fiel Mokhtar o de Jossie Joy. La mirada humanizada con que se ofrecen carece de toda crueldad, por muy grotescos o extravagantes que sean, como Samantha Jallah o las lelés que la acompañan. También, como un personaje más, silente pero abrumador, está la selva, el conflicto bélico, esa estrechez y primitivismo continuos, el 
paisaje exótico de las poblaciones africanas reconstruido con precisión, lo que revela una sólida labor de investigación llevada a cabo por López-Peláez.

De alguna manera esta novela acerca el género a su predecente, la epopeya -al fin y al cabo toda búsqueda literaria remite a la Telemaquia-, por el carácter simbólico o alegórico más arriba insinuado, al tiempo que propende a una reflexión sobre las contradicciones y miserias del hombre, tal vez atenuada por la visión de cierta confianza en el sentido del deber hacia los otros y su altura moral frente a la derrota y la adversidad. El sentido del deber y su cumplimiento es lo que forzó la desaparición del diplomático y lo que empuja al protagonista a buscarlo. En ambos casos su significado se basa en un cumplimiento no maquinal o inconsciente, sino en una visión a la manera estoica, en la que el deber es vislumbrado como única salvaguarda moral ante el caos y la adversidad. Por ello también se lleva al límite, sin jactancia ni heroísmo, tanto por el protagonista como -intuimos- por el diplomático desaparecido, frente al cinismo del padre Jarosz, frente al distanciamiento defensivo del fotógrafo La Salle, frente a la irracionalidad imperante y frente a personajes como Prince Yomi o los sanguinarios bandidos de Charles Ghangay, aunque conduzca, como sucede al ausente -y podría repetirse en quien lo busca-, a una probable autodestrucción. Sin embargo, pese a esa luz oculta entre las sombras, es inevitable entrever tal vez una conclusión negativa acerca de la cruel condición del hombre, su organización política puesta en solfa, el significado del poder...

La perfecta ambientación de la historia o ese estilo sutil, diáfano, despojado, pero, al mismo tiempo, tremendamente certero (que sin duda, más allá de ámbito hispánico, remite a Hemingway, a Carver, a Steinbeck...), que pudieran parecer otorgarle un carácter documental o de reportaje periodístico, no deben confundir al lector. Estamos ante una obra literaria, que, partiendo de un correlato real, propone algunas cuestiones profundas presentes en buena parte de la historia de la literatura: la lucha entre valentía e injusticia, la confrontación entre la crueldad y la esperanza, la toma de postura ante la adversidad... Ignoramos si todas estas significaciones se hallaban en el deseo original del autor, pero resulta indudable que laten de alguna manera más allá de la mera anécdota novelesca, por la acumulación de sobreentendidos, de silencios, de alusiones o emociones que sustentan con firmeza, como un andamiaje profundo, todo el entramado de esta ficción novelesca.

Mario Paz González 